УДК/UDC 4414

\title{
НЕКОТОРЫЕ ОСОБЕННОСТИ ПОЛОЖЕНИЯ И ЗАЩИТЫ ПРАВ МИНОРИТАРИЕВ В РОССИИ
}

\author{
Гаврилова Ангелина Константиновна \\ Студентка 4 курса юридического факультета \\ Кубанский Государственный Аграрный университет \\ Краснодар
}

\section{SOME FEATURES OF THE POSITION AND PROTECTION OF THE RIGHTS OF MINORITY SHAREHOLDERS IN RUSSIA}

\author{
Angelina Gavrilova \\ 4th year student of the Faculty of Law \\ Kuban State Agrarian University \\ Krasnodar
}

\begin{abstract}
Аннотация. На сегодняшний день выделяется некоторая категория акционеров, права которых сильно ограничиваются и нарушаются. Такой категорией акционеров являются миноритарии. Данная научная статья посвящена рассмотрению некоторых вопросов правового положения миноритариев в Российской Федерации. Во многих странах мира, в том числе в России, законодательство содержит ряд норм, направленных на защиту миноритариев. Автор высказывает мнение о необходимости учитывать баланс частных и публичных интересов миноритарных акционеров. Несоблюдение такого баланса может привести к негативным последствиям не только для самих миноритариев, но и для акционерного общества в целом, для отношений между акционерным обществом и учредителями. Рассматриваются специфические права, предоставляемые законом держателям определенных пакетов акций компании. Рассмотрены возможности дальнейшего совершенствования законодательства в области обеспечения прав миноритарных акционеров. С учетом сложившейся практики хочется отметить, что на сегодняшний день существует достаточное количество способов защиты прав миноритарных акционеров, которые закреплены в действующих нормативно-правовых актах, но нуждающихся в доработках.

Abstract. Today, a certain category of shareholders stands out, whose rights are severely limited and violated. This category of shareholders is minority shareholders. This scientific article is devoted to the study of the legal status of minority shareholders in the Russian Federation. In many countries of the world, including Russia, the legislation contains a number of provisions aimed at protecting minority shareholders. The author expresses the opinion that it is necessary to take into account the balance of private and public interests of minority shareholders. Failure to comply with such a balance can lead to negative consequences not only for the minority shareholders themselves, but also for the joint-stock company as a whole, for the relationship between the joint-stock company and the founders. The purpose of the article is to identify the main possible violations of the rights of minority shareholders and analyze the main ways to protect these rights. The specific rights granted by the law to the holders of certain blocks of shares of the company are considered. The possibilities of further improvement of legislation in the field of ensuring the rights of minority shareholders were considered. Taking into account the current practice, I would like to note that today there are a sufficient number of ways to protect the rights of minority shareholders, which are enshrined in the current regulatory legal acts, but that need to be improved.
\end{abstract}

Ключевые слова: миноритарий, акция, законодательство.

Key words: minority shareholder, share, legislation.

Одной из актуальных проблем регулирования корпоративных отношений на сегодняшний день считается проблема защиты прав миноритариев (мелких акционеров) и органов управления акционерными обществами для обеспечения реального участия акционеров небольшого количества акций. На сегодняшний день в российской науке и в законодательстве много внимания уделяется защите прав миноритарных акционеров. Модернизировать российскую экономику и увеличить количество акционерных компаний можно лишь добившись соблюдения баланса публичных и частных интересов.[1]

Права миноритариев закреплены в Федеральном законе «Об акционерных обществах». Права защищаются с помощью определения большинства голосов по ключевым факторам: реорганизация, изменение, ликвидация устава общества, эмиссии и т. п. (пп. 1-3, 5, 17 п. 1 ст. 48). Развитие правовой защиты миноритариев - одно из актуальных направлений государственно-правовой политики в сфере улучшения корпоративных отношений. [2]

Однако, исходя из нововведений, акционеры, имеющие более $1 \%$ вкладов, имеют ограниченный доступ к корпоративной информации из-за введения условного перечня доступных сведений: наиболее прибыльные 
сделки и текстограмма заседания директоров. Миноритарии имеют полный доступ к договору об организации общества, о его государственной регистрации, аудит, отчеты об эмиссии ценных бумаг, протоколы общих собраний акционеров, а также заключения ревизора объединения. К бухгалтерской отчетности и заседаниям совета правления имеют доступ только акционеры, которые имеют более чем 25\% голосующих акций. Однако, имеется возможность утвердить в уставе организации иные порог и условия для предоставления различной корпоративной информации.

Держатели менее 25\% голосующих акций имеют право запрашивать ту или иную информацию лишь указав цель и обоснованность ее получения, которые в свою очередь могут быть не приняты, если общество сочтет их неудовлетворительными или запрашивающий акционер имеет связь с конкурентами, так как вся корпоративная информация имеет статус конфиденциальности.[3]

В 2006 г. В Федеральный закон от 26 декабря 1995 г. № 208-Ф3 «Об акционерных обществах» были внесены новые положения о выкупе более 30\% акций. Они спровоцировали судебные иски и разбирательства, инициируемые миноритариями, стремящимися повлиять на этот процесс, так как он принудительный выкуп акций мажоритарием. В постановлении Конституционного Суда от 21 апреля 2003 г. № 6-П, где утверждается, что ограничение федеральным законом имущественных прав должно не нарушать закон и сущности конституционных прав.

Основанием для отчуждения у миноритариев их акций является доминирующая роль интереса акционерного общества в целом: миноритарий выступает в контексте субъекта, злоупотребляющего полномочиями, имеет право оспаривать сделки и акты общества через иски, что может якобы отрицательно влиять на цели мажоритария, и не имеет право участия в принятии обществом решений по причине недостающего числа акций. Видится, что Конституционный Суд РФ отдает доминирующую роль акционеру мажоритарию через предоставление права принудительного выкупа ценных бумаг, при этом возмещая компенсацией миноритариям. В качестве повышения эффективности соблюдения баланса интересов выдвигается инициатива контролирующей функции судебными органами за оценкой стоимости выкупаемых акций и понесенных истцом убытков [4]. Функцией оценки судом обстоятельств нарушения закона при выкупе либо при возникновении права на выкуп о несправедливой цене на акции [5]. Также доминирование мажоритариев рассматривается в том, что миноритарии не имеют возможности и механизмов результативно влиять на вопросы управления обществом. Презумпция недобросовестности держателей малых акций не должна оправдываться. Отсутствует статистика отрицательного влияния статуса миноритарных компании. Ряд исследователей, полагают не совсем корректным положение, что превышение прав миноритарием должно быть причиной потери статуса акционера [6].

Ограничения, утвержденные в новом законе, ставят статус миноритария в условное положение, ставя его зависимость от руководящей роли мажоритариев в управлении организацией, что в последствии нарушает баланс этих субъектов в корпоративном праве. Законодатель вместе с Конституционным Судом Российской Федерации считает, что какой-то процент акций миноритарных акционеров в большинстве случаев является лишь основой для злоупотребления корпоративным правом.[7] Данную ситуацию нельзя исключать, но также нужно помнить, что, если лицо, которое является управомоченным, не может реализовать свой законный интерес через реализацию субъективного права, оно будет активно пытаться ее злоупотребляя принадлежащим ему правом.

Исходя из вышесказанного, можем сделать вывод, что миноритарии нуждаются в защите своих прав. В связи со существующими сложностями в их деятельности, необходимо, на наш взгляд, ввести институт акционерных соглашений, который бы регулировал и проверял соблюдение права миноритариев.

\section{Библиографический список:}

олинская В. В., Фалеев В. В. Миноритарные акционеры: статус, права и их осуществление. М., 2010.

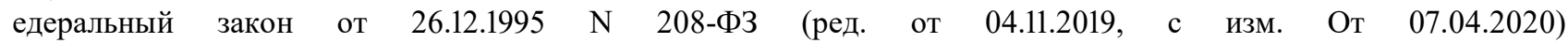
«Об акционерных обществах» (с изм. и доп., вступ. в силу с 01.01.2020) // СПС Консультант Плюс. 2. Постановление Конституционного Суда РФ от 30 октября 2003 г. № 15- П // СЗ РФ. 2003. № 44. Ст. 4358.

3. Постановление Конституционного Суда РФ от 21 апреля 2003 г. № 6-П // С3 РФ. 2003. № 17. СT. 1657.

4. Альмурзиева Ф.М. Правовые позиции Конституционного Суда РФ по вопросу ограничения прав акционеров // Вестник ОмГУ. Серия. Право. 2013. № 3 (36).

5. Постановление Конституционного Суда РФ от 24 февраля 2004 г. № 3- П // СЗРФ. 2004. № 9. Ст. 830.

6. Ломакин Д.В. Корпоративные правоотношения: общая теория и практика применения в хозяйственных обществах. М., 2008

7. Бережной А.Ю., Марченко Т.В. Особенности понятий: крупный акционер, крупный пакет акций, миноритарный акционер, корпоративный контроль // Теоретические аспекты юриспруденции и вопросы право применения: сборник статей по материалам II международной научно практической конференции. М., 2017. 